\title{
Game Learning to Optimize Learning and Trauma Healing in Children After Disaster in Banyumas
}

\author{
Rafika Bayu Kusumandari ${ }^{1}$, Basuki Wibawa ${ }^{2}$ and Hartati Muchtar ${ }^{3}$ \\ Educational Technology, Universitas Negeri Jakarta, Jl. Pemuda, Jakarta Timur, \\ Indonesia $^{1,2}$ \\ Educational Technology, Universitas Negeri Jakarta, Jakarta Timur, Indonesia ${ }^{3}$ \\ rafikabayu_tp15s3@mahasiswa.unj.ac.id ${ }^{1}$,bwibawa@unj.ac.id ${ }^{2}$, hartati muchtar@yahoo.co.id ${ }^{3}$
}

\begin{abstract}
The purpose of this study was to determine the effectiveness of learning games to improve learning and reduce trauma to children affected by postdisaster disasters. The research method used was Rn D. The results of the study showed that the utilization of learning games to optimize post-disaster learning in disaster areas. Where from 17 children who were victims of the disaster, they were very fond of game-based learning. On the other hand, the use of learning games can also reduce trauma to children affected by disasters after the disaster.
\end{abstract}

Keywords: Game Learning, Optimize Learning, Reduce Trauma for Children, Disaster Area.

\section{Introduction}

Indonesia is a country located on a ring of fire that stretches along the Pacific plate which is the most active tectonic plates in the world. This zone contributes almost $90 \%$ of the occurrence of earthquakes that occur. According to data from the Indonesian Disaster Information Database (DIBI) -BNPB, out of 1,800 disasters over the period 2005-2015 over $78 \%(11,648)$ disaster events are hydro meteorological disasters and $22 \%(3,810)$ are geological disasters.

As for the frequent groups of geological disasters are earthquakes, tsunamis, volcanic eruptions, and landslides. This condition causes the destruction of various facilities including infrastructure in the world of education so that often hinder the learning process. Though education is a very valuable investment in human life. Therefore, various developments continue to be made to create various learning alternatives in supporting the education process.

The use of technology will help the implementation of the learning process although facilities and infrastructure are minimal. This technology-based learning alternative is expected to answer the problem of limited educational facilities and infrastructure and reduce trauma in children after the disaster.

One of the technologies used is the use of smartphones for learning. In addition, there are many game features that not only as entertainment to play, but there are many games to hone the power of thought and logic that can introduce the material to be more interesting to be accepted and understood especially by the child. 
By using Android-based learning game is expected to be an alternative model of education that is effective, interesting, interactive and fun.

\section{Literature Review}

Learning is the development of knowledge, skills, or attitude as an individual interacts with information and environment. Furthermore, Kusumandari \& Istyarini says that learning is defined as a deliberate effort by educators to support student learning activities. Instructional was viewed as the transmission of information. The role of the student was to respond to the stimuli effectively. The role of instructor was to design and present the correct and appropriate stimuli to elicit the appropriate behavior.

The use of appropriate learning strategies can improve the quality of learning. Quality learning can achieve learning objectives optimally.

\subsection{Learning Game}

Game are a multimedia platform, not a single medium of delivering the experience [1]. In an educational context games have the ability to make learning more entertaining and motivate students without compromising the learning [2].

Game-based learning is a type of game play with defined learning outcomes [3] Salen \& Zimmerman defines a game as a system in which players engage in an artificial conflict, defined by rules, that results in a quantifiable outcome. We argue that for games to achieve their potential for learning, all these perspectives have to be taken into account, with specific emphases depending upon the intention and design of the learning game [4].

A major reason for educators to combine gaming with education is the high motivational capacity of games. Activating this potential of enjoyment for education promises effortless learning, even of contents most students do not like to learn (Boeker, et al. 2013). Bradsaw \& [5] the use of games for learning is a rather ancient technique, for example, games were used to coach soldiers for war. If education can be fostered through such a highly motivational media, it will be a win-win situation for everyone involved in the field of education [6].

Games can be designed such that students are presented with problems in an environment that allows them to make mistakes and reflect upon them [7]. [8] says that games could be a useful tool for building a learning space in which learners could test experiential learning paths. One of the requirements for the game to be a source of learning and development is time. Every game must have a certain duration to make the child acquire those previously mentioned skills [9].

Games meet the fundamental needs of learning by providing us with enjoyment, passionate involvement, structure, motivation, ego gratification, adrenaline, creativity, social interaction and emotion [10]. Cojocariu \& Boghian says that game is specially conceived for the instructive-educational context, integrated and fully exploited inside it, under careful supervision and monitoring of teachers. [11] says that take advantage of game characteristics to arouse student interest; enable students to enjoy learning while they take control of learning; and periodically assess learning effectiveness and improve teaching.

\subsection{Learning Game}

For the past decade, Indonesia, a disaster-prone country, has been struck by natural disasters that have produced huge numbers of casualties, direct losses, and damaged infrastructre [12]. The causes of natural disasters such as flooding, changes in sea level, wildfires (and associated deforestation) are being associated with climate change [13] 
Crises and disasters cannot be avoided, but their consequences can be mitigated by planning, exercises and preparedness [14].

Bright, et al reported that games generate enthusiasm, excitement, total involvement and enjoyment. Booker (2014) has stated that one of the advantages of playing games with peers is the quick feedback primary children receive.

\section{Method}

The research method used is the R N D research method. Research and development methods are research methods used to produce certain products, and test the effectiveness of these products. Educational Research and Development is a process used to develop and validate educational [15]. Developmental research, as opposed to simple instructional development, has been defined as the systematic study of designing, developing, and evaluating instructional programs, processes, and products that must meet criteria of internal consistency and effectiveness [16].

In the development process using qualitative descriptive methods. [17] says that inquirer seeks to examine an issue related to oppression of individuals. To this study, stories are collected of individual oppression using a narrative approach. Individuals are interviewed at some length to determine how they have personally experienced oppressions. As a qualitative researcher, it is vital for the interviewees to trust you. Overcoming the lack of trust with many of the interviewees took time and effort, including providing my resume, my detailed background information, IRB paperwork, overview of the study, and rescheduling the interviews [18]. Furthermore [19] argued that base in qualitative methods; its practices blur the boundaries of aesthetics and experience in an effort to capture and reflect the complex dynamics involved in the phenomenology of artistic practice.

To overcome this tension the phenomenographic research method was used in a manner that was unusual in several respects. A key feature was that the qualitative phenomenographic process was combined with a before-and-after quantitative frequency analysis of the number of student responses falling into each category of description, which were part of the outcome from the phenomenographical study [20].

Thus, this qualitative method can be used to describe the results of research on the application of android-based learning games to optimize learning and reduce trauma to postdisaster children in disaster areas.

For the testing process, researchers compiled a grid of research instruments, from the research instruments then compiled research instruments and interview guidelines. As for products, researchers design product designs by first outlining program content and program scripts.

\section{Result and Discussion}

\subsection{Result of Research}

The research activity began with the management of research permits to BPBD Banyumas Regency, from BPBD Banyumas Regency.

After getting a recommendation for the location of the study then contacting the Village Chief of Cihonje to request permission to collect data. For the implementation of learning, researchers are assisted by two volunteers, who are also teachers and are victims of the disaster. The activity is held for 7 meetings every Friday, Saturday and Sunday every week. This is done to see the development of learning outcomes and decrease trauma in post-disaster children. To make it easier to describe the results of the study, the results of activities per day are presented starting from the first day to the seventh day. 
The study was conducted at the Baiturahman Mosque in Gumelar District, Banyumas Regency. To assist in the implementation of the activity, it was assisted by Ms. Rom and Mrs. Ida. From the field test carried out during 7 times meetings where the results are as follows.

The table above shows that the increase in student learning outcomes is shown by the increasing value scores that students achieve. Whereas for the reduction of trauma in children is shown by the faster the time needed by students to complete the game.

The activity was held in TK Pertiwi Ciwaras hall. There were 17 children who were respondents to the study. The location of the hall is 300 meters from the location of the landslide so it is safe. The children came with their mother. The researcher was helped by two volunteers who were indigenous Ciwaras, TK Pertiwi teachers and were victims of the disaster. When the activity starts, the children sit near their mothers. The activity begins with volunteers to introduce who the researcher is and provide an opportunity for researchers to introduce themselves. The researcher introduces himself and conveys the purpose of the activity. After the researchers introduced themselves, children and their mothers were asked to introduce themselves. It seems that children tend to be closed and prefer to be near their mother. Even if they want to mingle, they tend to be not far from their mothers.

The researchers approached the children by greeting them one by one, stroking their heads and backs. Trying to give a sense of security and comfort because it was the first time you met. Volunteers help to convince children that researchers are not bad people. Children's voices tend to be small when introducing themselves. They still don't want to be open. The researcher asked who had the cellphone, all the children answered. Their mother helped convince her children to get closer to the researcher when delivering information related to the learning game that would be used for learning. Then the researchers examined one by one HP owned by children, where it was found out of 17 children there was only 1 child who had a cellphone not based on Android. For this reason, the researcher lent the cellphone to the child so that when his friends were playing a game, he also played the same game.

First of all, the researchers asked the children to write HP numbers on paper which were circulated because they would be filled with internet pulses. After all the children write their cellphone numbers, the researchers fill each number with the packet internet pulse for the purpose of downloading the Airbnb program so that the learning game program can be downloaded on each child's cellphone. After the Airbnd program is downloaded, the researcher sends the game learning program through the Shareit program so that in a short time all children can receive the program. After the program is divided, the children download it on each cellphone. The learning game program is ready to use.

To facilitate making observations, researchers divided into 6 groups, where each group contained 3 people as many as 5 groups and 2 people as many as 1 group. To observe the extent to which learning can be optimized and at the same time reduce trauma to children affected by post-disaster disasters, researchers were assisted by 6 volunteers namely Yunita, Anisa, Aris, Nurhasanah, Taufik, and Dedi who were S1 students and joined volunteer victims. Each volunteer is tasked with calculating how quickly the children can complete the game and how much score they have achieved and what the behavior of the child victims of the disaster is. The speed of completing the game and the number of scores they achieved can be used as a reference to see how effective the program can be to help students learn while reducing their trauma by playing learning games.

\subsection{Discussion}

Effective learning games are used to improve learning in disaster areas and to reduce trauma to children affected by disasters in disaster areas. reducing trauma in children after 
they play the learning game can be seen from the changes in attitudes and behavior of children from the first meeting to the last meeting. At the first and second meetings, they still need support from their parents to accompany them. The second meeting was about to sit alone even though there were their mothers around the activity site. The third meeting, really wanted to be alone even though they still had to be delivered by their mother. At the fourth to last meeting, they were truly independent. They also look cheerful and want to blend in with volunteers.

\section{Conclusion}

To optimize learning in disaster areas post-disaster can use learning games. Learning games can also be used to reduce trauma to post-disaster children.

\section{Acknowledgements}

Acknowledgments the researcher conveyed to the DPRM Kemenristek Dikti which gave the opportunity for researchers to obtain the Doctoral Dissertation Research Grant.

\section{References}

[1] S. J. Warren and G. Jones, "No Title," in Learning Games: The Science and Art of Development, USA:SPRINGER, .

[2] C. I. Muntean, "Raising engagement in e-learning through gamification," in The 6th International Conference on Virtual Learning ICVL, vol. 323, p. 329.

[3] D. W. Shaffer, R. Halverson, K. R. Squire, and J. P. Gee, "Video Games and The Future of Learning, WCER Working."

[4] J. L. Plass, D. B. Homer, and C. K. Kinzer, "Foundations of Game-Based Learning," Educ. Psychol., vol. 50, no. 4, pp. 258-283.

[5] M. J. Bradshaw and A. J. Lowenstein, Innovative teaching strategies in nursing, 4th ed. SUDBURY: JONES: AND BARTLETT.

[6] K. Amr, Learning Through Games: Essential Features of An Educational Game. Dissertation. Syracruse University.

[7] M. K. Pedersen, "DiffGame: Game-based Mathematics Learning for Physics," in Procedia - Social and Behavioral Sciences 228, .

[8] D. La Guardia, "A Game Based Learning Model for Entrepreneurship Education," in Procedia - Social and Behavioral Sciences 141, .

[9] F. M. M. Lucas, "The game as an early childhood learning resource for intercultural education," in Procedia - Social and Behavioral Sciences 237, .

[10] M. Prensky, "Fun, Play and Games: What Makes Games Engaging," in Digital GameBased Learning, Chapter 5, MCGRAW-HILL, NEW YORK.

[11] H. Rui, Y. Liu, Whinston, and A., "Whose and what chatter matters? The effect of tweets on movie sales," Decis. Support Syst. Vol, vol. 55, no. 4, pp. 863-870.

[12] D. Pascapurnama, "in Disaster Risk Reduction: Lesson Learned fromDisease Outbreak Natural Disasters in Indonesia," Integr. Heal. Educ., vol. 29, pp. 94-102.

[13] J. Preston and er. Al, "Community response in disasters: an ecological learning framework. International Journal of Lifelong Education ISSN: 0260-1370,” in (Print) 1464-519X (Online) Journal homepage, .

[14] A. K. Manesh, "Youth Are Our Future Assets in Emergency and Disaster Management," Bull Emerg Trauma, vol. 1, no. 1-3.

[15] Borg and Gall, Research: An Introduction. NEW YORK: PRESTICE HALL. 
[16] R. C. Richey, Developmental Research: The Definition and Scope. London:ERIC.

[17] J. W. Creswell, Research Design of Qualitative, Quantitative and Mixed Method Approaches. Yogjakarta: Pustaka Pelajar.

[18] M. Murphy, "Habermas and Social Research: Between Theory and Method," in London:ROUTLEDGE ADVANCES IN SOCIOLOGY, .

[19] E. Barret and B. Bolt, Approces to Creative Arts Enquiry. London: I.B. TAURIS.

[20] J. Huisman and M. Tight, "Theory and Mehtod," in Higher Education Research, London:EMERALD, 